\title{
Overview of Phacidiales, including Aotearoamyces gen. nov. on Nothofagus
}

\author{
Luis Quijada1 ${ }^{1}$ Peter R. Johnston², Jerry A. Cooper ${ }^{3}$, and Donald H. Pfister ${ }^{1}$
}

${ }^{1}$ Department of Organismic and Evolutionary Biology, Harvard Herbarium, 22 Divinity Avenue, Cambridge MA 02138, United States of America; corresponding author e-mail: luis_quijada@fas.harvard.edu

2Manaaki Whenua Landcare Research, Private Bag 92170, Auckland 1072, New Zealand

${ }^{3}$ Manaaki Whenua Landcare Research, P.O. Box 69040, Lincoln 7640, New Zealand

\begin{abstract}
The new genus Aotearoamyces is proposed to accommodate a single species that was repeatedly collected on fallen wood in Nothofagaceae forests of New Zealand and was previously misidentified as a Claussenomyces species. This monotypic genus belongs to Tympanidaceae, a recently erected family in Phacidiales. Aotearoamyces is differentiated from other Tympanidaceae by phragmospores that do not form conidia either in or outside the asci, an exciple of textura intricata with hyphae widely spaced and strongly gelatinized (plectenchyma), and apically flexuous, partly helicoid paraphyses. The asexual morph was studied in pure culture. Phylogenetic analyses of combined SSU, ITS and LSU sequences strongly support a sister relationship between the sexually typified Aotearoamyces and the asexually typified "Collophorina" paarla characterized morphologically by forming endoconidia, a feature not found in the genetically distinct type species of Collophorina. Based on our molecular results, we place the genus Epithamnolia in the Mniaecia lineage within Phacidiales.
\end{abstract}

Key words: Ascomycota Claussenomyces new taxa Nothofagus phylogeny Rhytismatales Leotiomycetes

Article info: Submitted: 20 April 2018; Accepted: 25 October 2018; Published: 30 October 2018.

\section{INTRODUCTION}

The taxonomy and classification of the Leotiomycetes is unsettled with a high proportion of taxa not yet treated using molecular methods (Baral 2016, LoBuglio \& Pfister 2010). Consequently, the delimitation of genera, families and orders often changes and the systematic position of taxa is subject to modification, depending on individual researcher's opinions, the impact of the addition of sequences from previously unsampled taxa, opinions about the acceptance of paraphyletic groups, etc. One of the orders recognized in the class is Phacidiales. A study of the genera considered to belong in this order provides a good example of the chaotic situation within the class.

The name Phacidiales was firstly used by Bessey (1907) and was described as including "true fungi, mostly saprophytic, but sometimes parasitic, with a branching septate mycelium, which bears the mostly open spore fruits (apothecia)". Three families were included in this initial circumscription, each with two genera (Fig. 1). Ten years later, Höhnel (1917) used the same ordinal name for six families and 52 genera (Fig. 1): Schizothryrieen (5 genera), Leptopeltineen (13 genera), Dermopeltineen (10 genera), Phacidiaceen (12 genera), Phacidiostromaceen (4 genera) and Cryptomyceteen ( 8 genera). Nowadays the only genus among those listed by Bessey or Höhnel which remains in the Phacidiales is the type genus Phacidium (Fig. 1). Most of the genera treated by Höhnel (1917) are still accepted, but the majority are now distributed across other orders or their position is uncertain because of a lack of DNA sequence data (Baral 2016, Wijayawardene et al. 2017).

How the number of genera and their systematic placement, which reflects changes in morphological concepts, has changed over time is illustrated in Fig. 1. Höhnel (1917) described the Phacidiales as follows: "Discomycetes with superficial or immersed fruitbodies, never erumpent fruitbodies, with or without stroma, excipulum entire or only at the margin, thin and brown or thick and carbonaceous. At maturity it opens very irregularly by a longitudinal split or by several lobes. Rarely the covering layer over the hymenium forms a detaching lid". After Höhnel's circumscription, the sexual morph was usually described as a reduced carbonaceous ascoma: black, discoid to hysteriform, frequently immersed in the tissue of the host and with a reduced exciple. The hymenium was described as exposed by a rupture of the upper stromatal layer by one or more slits. The asci were reported as 4-8-spored, thickened apically, with or without an amyloid apical ring. The ascospores were referred to as variable in shape, simple or phragmoseptate, hyaline or rarely brownish, and with or without mucilaginous sheaths or appendages (e.g. Ainsworth \& Bisby 1943, 1950, Ainsworth 1961, Korf 1973, Dennis 1978). The concept of the order that developed after Höhnel generally included three families (Fig. 1): Cryptomycetaceae, Hypodermataceae or Rhytismataceae, and Phacidiaceae (e.g. Ainsworth et al. 1971, Korf 1973, Dennis 1978, DiCosmo et al. 1984).

Between 1983 and 1995 the order Phacidiales fell out of use, and the family Phacidiaceae was applied in a more restricted sense, including Phacidium and two or three other

๑ 2018 International Mycological Association

You are free to share - to copy, distribute and transmit the work, under the following conditions:

Attribution: $\quad$ You must attribute the work in the manner specified by the author or licensor (but not in any way that suggests that they endorse you or your use of the work).

Non-commercial: $\quad$ You may not use this work for commercial purposes.

No derivative works: You may not alter, transform, or build upon this work.

For any reuse or distribution, you must make clear to others the license terms of this work, which can be found at http://creativecommons.org/licenses/by-nc-nd/3.0/legalcode. Any of the above conditions can be waived if you get permission from the copyright holder. Nothing in this license impairs or restricts the author's moral rights. 


\section{Cryptomyceteen}

Colpoma

Cryptomyces

Myxophacidiella

Myxophacidium

(= Mellitiosporium $)$

Sporomega

$\square$

Sporomega

Xylopezia

$\square$

Schizothyrieen

Clypeolum

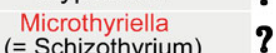

Phacidiostromaceen

Aporhytisma
(= Diaporthe)

(= Rhytisma)

Phacidiostrom

Placuntium
(= Rhytisma)

Dermopeltineen

(= Coccomyces)

= Lophodermium)

Hypodermella

Hypodermellina

Lophodermellina

Macroderma

Nymanomyces

Pseudophacidium

Pseudotrochila

(= Rhytisma)

Phragmoohyriella ?

(= Myriangiella)

?

Schizothyrium ?

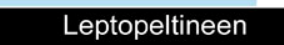

Bifusella

Coccomyces

Duplicaria

Entopeltis

Haplophyse

(= Leptopeltella

Leptopeltis

Lophodermina
(= Lophodermium)

Phacidina

Rhytisma

Schizothyrioma

Thyriopsis

Vizella

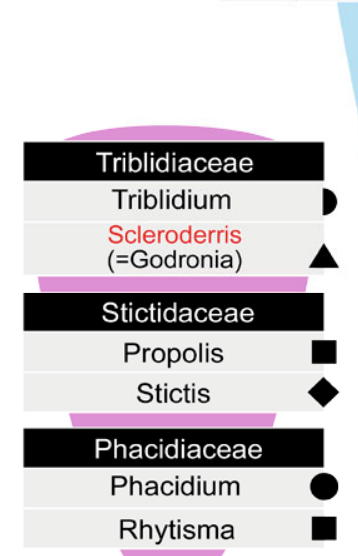

Aldona

Coccomycetella

Cryptomycina ?

Hymenobolus

Hysteropsis ?

Lophodermium

Moutoniella

(= Naeviala)

Odontotrema

Phacidium

Phaeophacidium

Sphaeropezia
Rhytismataceae

Bifusella

Bifusepta

Ceratophacidium

Coccomyces

Colpoma

Davisomycella

Duplicaria

Elytroderma

(= Lophodermium)

Hypodermella

Isthmiella

Lirula

Lophodermella

Lophodermium

Lophomerum

Nymanomyces

Placuntium
(= Rhytisma)

Ploioderma

Rhytisma

Soleella

Virgella

Cryptomycetaceae

Cryptomyces

Pseudorhytisma

Phacidiaceae

Cryptomycina

Lophophacidium

Micraspis

Nannfeldtia

Neophacidium

Phacidina

Phacidium

Pseudophacidium

Therrya

Symbols denote current placemet

$\downarrow$ Asterinales

- Phacidiales

$\nabla$ Diaporthales

- Rhytismatales

A Helotiales

D Triblidiales

Ostropales

- Xylariales

? Incertae sedis

\section{Hypodermatace}

Bifusella

Coccomyces

Colpoma

(= Lophodermium)

Hypodermella

Lophodermium

Rhytisma

Sporomega

Terriera

Cryptomycetaceae

(= Phacidiopycnis)

Cryptomyces

Phacidiaceae

Cryptomycina

Didymascella

Laquearia

Lasiostictis

Mellitiosporium

Micraspis

Naemacyclus

Phacidiostroma

Phacidium

Pseudophacidi

Rhabdocline

Sphaeropezia

Therrya

\section{$\square$ \\ a \\ 口 \\ ㅁ \\ ㅁ}

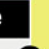

口

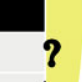

?

$\Delta$

-

0

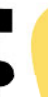

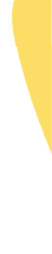

cidiaceae

Allantophomopsiella

Allantophomopsis

Bulgaria

Phacidium

Potebniamyces

Pseudophacidium
Incertae sedis

Coma

Mniaecia lineage

Mniaecia

?Trizodia

Tympanidaceae

Claussenomyces

Collophora

Durandiella

Grovesiella

Holwaya

? Micraspis

Myriodiscus

Pragmopora

Tympanis

Helicogoniaceae

Calloriopsis

Eleutheromycella

Eleutheromyces

Gelatinipulvinella

Gelatinopsis

Geltingia

Helicogonium

Phacidiaceae

Allantophomopsiella

Allantophomopsis

Bulgaria

Darkera

? Gremmenia

Lophophacidium

Phacidiopycnis

Phacidium

Pseudophacidium Starbaeckia 
genera. Some authors even considered Phacidiales as a synonym of Rhytismatales (Hawksworth et al. 1983). In other cases, Phacidiaceae, Cryptomycetaceae and Rhytismataceae were included in Rhytismatales (Hawksworth et al. 1983, 1995). Rhytismataceae and Hypodermataceae included many genera previously placed in Phacidiales (Hawksworth et al. 1983, 1995). In 1995 the family Phacidiaceae contained three genera and was placed by Korf \& Lizoň (2000) in Leotiales, an invalid name later validated by Korf \& Lizoň (2000), and there in Helotiales. In 2001 the Phacidiaceae still contained only three genera (Ascocoma, Lophophacidium, and Phacidium) and was transferred to Helotiales, where it was treated during 2001-2010 (Kirk et al. 2001, 2008, Eriksson 2005, 2006, Lumbsch \& Hundorf 2007, 2010).

Crous et al. (2014) recognized the Phacidiales as a monophyletic order distinct from Helotiales and included six genera (Fig. 1). Using molecular evidence, these authors expanded the morphological concept of the order by including genera with exposed, cup-shaped apothecia typical of helotiaceous fungi (e.g. Bulgaria) as well as genera with immersed ascomata that open by splits across covering stromatic layers, as was characteristic of the concepts of Phacidiales of earlier authors. Although DiCosmo et al. (1984) reported anamorphs for some members in Phacidiales, it was Crous et al. (2014) who provided a unified view of the asexual morphs within the order. Previously, the information about asexual morphs was sparse and only a relationship with coelomycetes had been reported (DiCosmo et al. 1984).

In the most recent classification of Leotiomycetes compiled by Baral (2016), the ecology of the order remained the same (saprobic, parasitic), but the morphological concept was expanded and delineated more precisely, including information about the phase during which the apothecia open (prohymenial to mesohymenial), and added features of the living cells, such as the lack of vacuolar bodies in paraphyses, asci with either amyloid or inamyloid apical rings (exceptionally the entire wall is amyloid) and ascospores with variable lipid content. Here the order Phacidiales has three families containing about 27 genera, approximately half the number of genera compared to Höhnel's concept a century ago (Fig. 1). Two to three genera were added to Phacidiaceae in addition to those considered by Crous et al. (2014): Darkera, Starbaeckia, and questionably Gremmenia. Also, the priority of Phacidiopycnis over the sexually typified Potebniamyces was indicated. Two new families were included in the order: Tympanidaceae and Helicogoniaceae. In addition to these three families in Phacidiales, Baral included the 'Mniaecia lineage' with one or two genera (Mniaecia, and ?Trizodia), and one genus as incertae sedis (Coma with the sexually typified synonym Ascocoma). Subsequently, Suija et al. (2017) placed the monotypic genus Epithamnolia as incertae sedis in Phacidiales, due to its phylogenetic and morphological affinities with the asexual morph of Epiglia (a synonym of Mniaecia fide Van Vooren 2005), thus widening the ecological concept of the order to include lichenicolous fungi.

Taking into consideration the repeated changes within Phacidiales, the aim of this research was to enhance and synthesize knowledge of the order. Important results include the erection of a new genus known only from the Southern Hemisphere for a species previously misclassified in Claussenomyces, and the observation that the asexual "Collophorina" paarla is related to it.

\section{MATERIAL AND METHODS}

Specimens of the newly described species were collected between 1989 and 2010 in native forests of New Zealand during non-targeted, general collecting expeditions for fungi. All specimens cited are deposited in the PDD fungarium (Manaaki Whenua Landcare Research, Auckland) and living cultures grown from ascospores from the fresh specimens are stored in the ICMP culture collection (Manaaki Whenua Landcare Research, Auckland, www.landcareresearch.co.nz/ resources/collections/icmp).

Sections for anatomical examination of ascomata were freehand sectioned under a Motic stereomicroscope SMZ140 and examined with a Motic B1 light microscope. Microphotographs were taken with an USB Moticam 2500 camera and processed with the software Motic images Plus 2.0. Measurements are given as follows: (smallest single measurement) smallest mean-largest mean (largest single measurement). The small and large means are based on $\geq 10$ measurements of individual specimens. No living specimens of the sexual morph were available, and therefore potassium hydroxide at $5 \%$ $(\mathrm{KOH})$ was used to rehydrate herbarium specimens prior to morphological study. Conidia and conidiogenous cells were measured from dried Oatmeal Agar cultures rehydrated in $5 \%$ $\mathrm{KOH}$. The descriptions and abbreviations follow Baral (1992): $\dagger=$ dead state, ${ }^{*}=$ living state; LBs = lipid bodies. Colour coding refers Anonymous (1976).

DNA was extracted from mycelia of cultures grown on agar plates from germinated ascospores from fresh collections, or from dried apothecia taken from fungarium specimens. DNA was extracted and amplified using PCR following the methods of Johnston \& Park (2013). Amplification primers used for the ITS1-5.8S-ITS2 region were ITS1F and ITS4 (White et al. 1990, Gardes \& Bruns 1993), for the LSU region were LROR and LR5 (Bunyard et al. 1994, Vilgalys \& Hester 1990), and for the SSU region were NS1 and NS4 (White et al. 1990). Purified PCR products were directly sequenced using the same primer pairs as in the PCR reactions. Partial sequences obtained in sequencing reactions were assembled with Sequencher 4.10.1 (Genecodes Corporation, Ann Arbor, MI). All sequences were deposited in GenBank (Table 1).

Fig. 1. Historical survey of systematic concepts of Phacidiales. Only information about the authors that accepted Phacidiales as an order is included. For each concept of the order, families are included in a black box and genera in a grey box, names in red are currently not accepted. Symbols at the right side of the box indicate the current ordinal placement of each genus according to Index Fungorum (2018) and Baral (2016), see explanation of symbols above. 
Table 1. Specimens used in this study with family information and GenBank accession numbers. Sequences of the new species are indicated in bold.

\begin{tabular}{|c|c|c|c|c|}
\hline \multirow[b]{2}{*}{ Species } & \multirow[b]{2}{*}{ Family } & \multicolumn{3}{|c|}{ GenBank number } \\
\hline & & ITS & LSU & SSU \\
\hline Sarcoleotia globosa 1 & Geoglossaceae & AY789410 & AY789409 & \\
\hline Sarcoleotia globosa 2 & Geoglossaceae & AY789300 & AY789299 & AY789298 \\
\hline Epithamnolia on Candelaria (HA90) & incertae sedis s. Suija et al. (2017) & KY814532 & KY814513 & KY814524 \\
\hline Epithamnolia on Lecanora (HA92) & incertae sedis s. Suija et al. (2017) & KY814526 & KY814508 & KY814519 \\
\hline Mniaecia jungermaniae & Mniaecia lineage & EU940185 & EU940109 & EU940036 \\
\hline Mniaecia nivea & Mniaecia lineage & EU940188 & EU940115 & EU940042 \\
\hline Mniaecia gloeocapsae & Mniaecia lineage & EU940204 & EU940128 & EU940055 \\
\hline Trizodia acrobia 1 & Mniaecia lineage & EU940190 & EU940113 & EU940040 \\
\hline Trizodia acrobia 2 & Mniaecia lineage & EU940191 & EU940114 & EU940041 \\
\hline Bulgaria inquinans & Phacidiaceae & KJ663831 & DQ470960 & DQ471008 \\
\hline Phacidium lacerum & Phacidiaceae & KJ663841 & DQ470976 & DQ471028 \\
\hline Phacidiopycnis pyri & Phacidiaceae & DQ491510 & DQ470949 & DQ470997 \\
\hline Allantophomopsis lunata & Phacidiaceae & KR873229 & KR873263 & \\
\hline Phacidium lauri & Phacidiaceae & KJ663850 & KJ663891 & \\
\hline Geltingia associata 1 & Helicogoniaceae & KJ559540 & KJ559562 & KJ559584 \\
\hline Geltingia associata 2 & Helicogoniaceae & & KJ559576 & KJ559580 \\
\hline Eleutheromyces subulatus 1 & Helicogoniaceae & NR145309 & EU754162 & EU754063 \\
\hline Eleutheromyces subulatus 2 & Helicogoniaceae & KJ710468 & KJ710444 & \\
\hline Eleutheromyces subulatus 3 & Helicogoniaceae & & EU754161 & EU754062 \\
\hline Collophorina africana 1 & Tympanidaceae & GQ154570 & GQ154609 & GQ154630 \\
\hline Collophorina africana 2 & Tympanidaceae & GQ154571 & GQ154610 & GQ154631 \\
\hline Collophorina paarla 1 & Tympanidaceae & GQ154586 & GQ154613 & GQ154634 \\
\hline Collophorina paarla 2 & Tympanidaceae & GQ154575 & GQ154611 & GQ154632 \\
\hline Collophorina rubra & Tympanidaceae & GQ154547 & GQ154606 & GQ154627 \\
\hline Holwaya mucida 1 & Tympanidaceae & KT225524 & AY544680 & AY544729 \\
\hline Holwaya mucida 2 & Tympanidaceae & DQ257357 & DQ257356 & DQ257355 \\
\hline Myriodiscus sparassoides & Tympanidaceae & JX219379 & JX219381 & JX219377 \\
\hline Claussenomyces prasinulus & Tympanidaceae & & KX090815 & KX090866 \\
\hline Aotearoamyces nothofagi ICMP 21969 & Tympanidaceae & KM677201 & MG807387 & MG807391 \\
\hline Aotearoamyces nothofagi ICMP 21968 & Tympanidaceae & KM677202 & MG807386 & MG807390 \\
\hline Aotearoamyces nothofagi PDD 106298 & Tympanidaceae & MG807392 & MG807388 & MG807389 \\
\hline
\end{tabular}

\section{Phylogenetic analyses}

An analysis using three different rDNA regions (SSU, ITS, LSU) for the representative members of Phacidiales was performed. This includes taxa from three families: Phacidiaceae ( 5 seq.), Helicogoniaceae (5 seq.) and Tympanidaceae (12 seq.). Also, five sequences of the Mniaecia lineage were included, and two representing the genus Epithamnolia, which was recently placed in Phacidiales as incertae sedis (Suija et al. 2017). Thirty-one taxa were used for the molecular analysis (Table 1). The sequences were aligned using the L-INS-i algorithm for the ITS region, and G-INS-i algorithm for SSU \& LSU (Katoth \& Toh 2008) with MAFFT v7.017 (Katoh et al. 2002). The program Gblocks v. $0.91 \mathrm{~b}$ was used to identify and eliminate ambiguously aligned regions (Castresana 2000), using the following relaxed settings (Talavera \& Castresana 2007): minimum number of sequences for a conserved or flanking position $=16$; maximum number of contiguous non-conserved position $=10$; minimum length of a block= 5 ; and gaps in an alignment column allowed in up to half the number of included sequences. The analyses were performed using the optimal model of nucleotide substitution identified with JModeltest (Posada 2008; http://darwing.uvigo.es), based on the Akaike information criterion (Akaike 1974). Maximum likelihood (ML) and Bayesian Inference (BI) analyses were performed using 


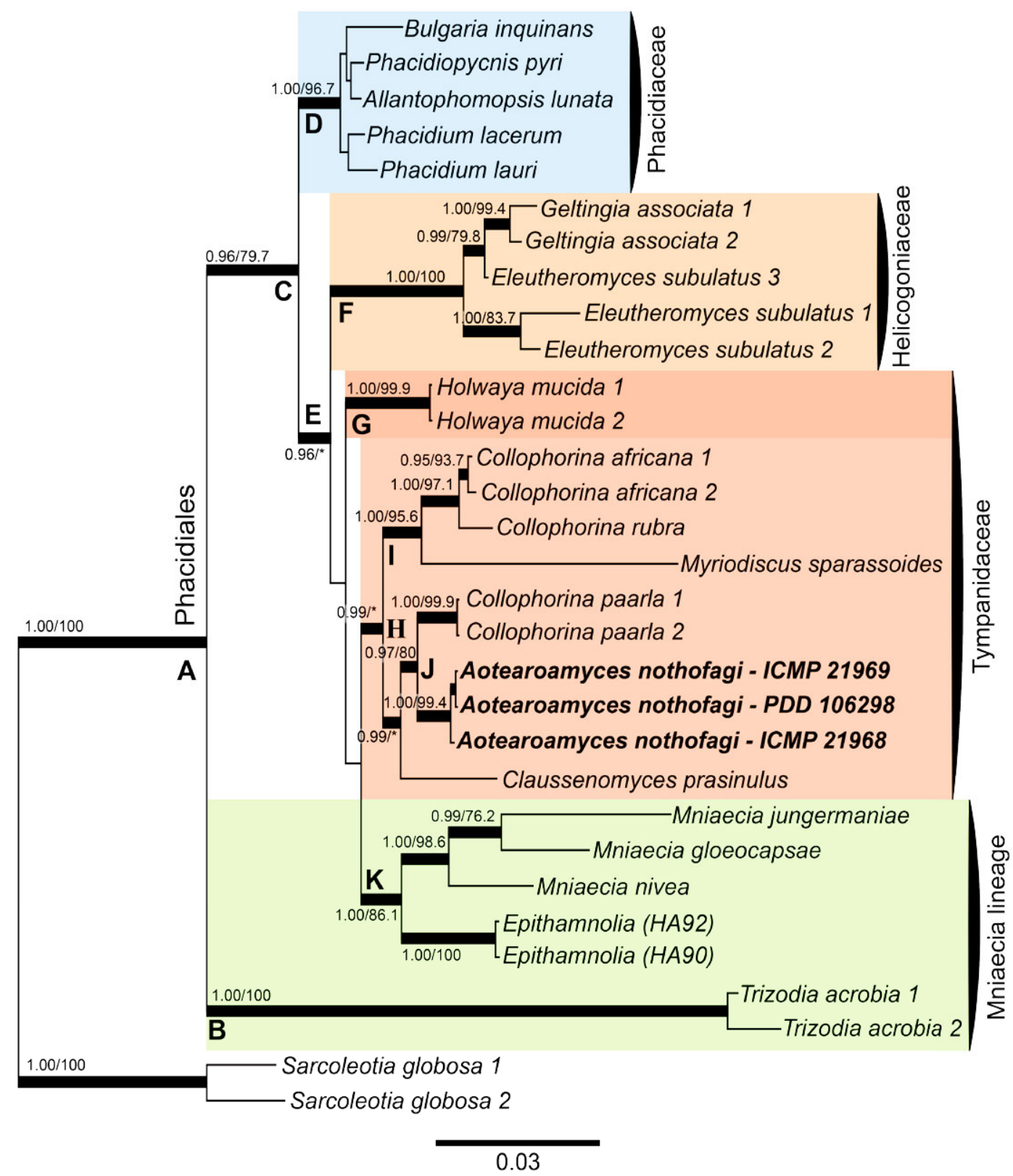

Fig. 2. Bayesian majority-rule consensus tree based on concatenated SSU, ITS, and LSU sequences. Bold branches are those which were well supported (see Methods) by ML/BI methods. Asterisks indicate a branch supported by only Bayesian methods.

Geneious v.6.1.7. Bayesian inference analyses followed Quijada et al. (2014), only varying in the number of starting trees (10 million generations) and the tree sampling (every $1000^{\text {th }}$ generation) for $\mathrm{BI}$ analysis. Branch support in $\mathrm{ML}$ was inferred from 1000 rounds of bootstrap. We only considered supported clades for ML those with bootstraps values $\geq 75 \%$ and with $\mathrm{PP} \geq 0.95$ (strongly supported) for BI. Phylogenetics trees were drawn with Geneious and artwork was prepared in Adobe Illustrator CS5.

\section{RESULTS}

Relationships among the members of Phacidiales were investigated for three regions (SSU, ITS, and LSU). The final alignment used for the phylogenetic analyses contained $3015 \mathrm{bp}$, with 599 variable and 405 parsimony-informative positions. The analyses identified at least 11 strongly supported clades (Fig. 2, clades A-K). Phacidiales (clade A: 1.00 BIPP, 100 MLBS) includes two main subclades: clade B (Trizodia, previously tentatively placed in the Mniaecia lineage; Baral 2016) and clade C (Mniaecia lineage; sensu Baral (loc.cit.) p.p., Tympanidaceae, Phacidiaceae, and Helicogoniaceae). The monophyletic clade K (1.00 BIPP, 86.1 MLBS) contains two genera (Epithamnolia and, Mniaecia). Clade E (0.96 BIPP, 47.4 MLBS) contains Helicogoniaceae, Tympanidaceae and the Mniaecia lineage. Phacidiaceae (clade D: 1.00 BIPP, 96.7 MLBS) and Helicogoniaceae (clade F: 1.00 BIPP, 100 MLBS) are monophyletic. Tympanidaceae is paraphyletic. Holwaya appears supported in a different clade (clade G: 100 BIPP, 99.9 MLBS) with respect to the other genera in Tympanidaceae (clade H: 0.99 BIPP, 51.7 MLBS). The genus Collophorina is paraphyletic and its members are in two clades of Tympanidaceae. Collophorina 
rubra and $C$. africana are together with Myriodiscus (clade I: 1.00 BIPP, 95.6 MLBS), and Aotearoamyces appears as a supported monophyletic clade in a sister relationship to Collophorina paarla (clade J: 0.97 BIPP, 80 MLBS).

\section{TAXONOMY}

Aotearoamyces P.R. Johnst., J.A. Cooper \& Quijada, gen. nov.

MycoBank MB825175

Etymology: The generic name refers to the indigenous name of New Zealand (Aotearoa) and the Greek name for fungi (myces).

Diagnosis: The sexual morph of Aotearoamyces resembles Holwaya mucida, but the apothecia are turbinate with the disc plane or slightly convex. Ascus and ascospore shape are similar to species of Claussenomyces, but without production of conidia or ascoconidia directly from the ascospores. Durandiella and Tympanis have similar exciples, but Aotearoamyces differs in hyphae that are strongly spaced and gelatinized. It differs from all the others members in Tympanidaceae by the curved or helicoid paraphyses. The asexual morph lacks endoconidia in the vegetative hyphae; conidiophores occur in well-developed synnemata; and conidia are small, 0-septate, hyaline and curved, formed by phialidic conidiogenesis.

Type species: Aotearoamyces nothofagi P.R. Johnst. et al. 2018

Classification: Tympanidaceae, Phacidiales, Leotiomycetes, Pezizomycotina, Ascomycota, Fungi.

Description: Ascomata apothecia, black, erumpent, short to medium long stipitate (to $1 \mathrm{~mm}$ tall), pulvinate-discoid to turbinate, solitary, or more commonly clustered in groups and arising from a common gelatinous stromatic base. Asci 8-spored, slightly thick-walled towards apex, inamyloid, arising from croziers. Ascospores cylindric-fusoid to fusoid-clavate and phragmoseptate, rarely with a longiseptum. Paraphyses apically flexuous to helicoid or curving downwards (hooked) and embedded in an olive-brown gelatinous matrix. Exciple of textura intricata, innermost layer of the exciple composed of a loose network of narrow hyphae, widely spaced and embedded in an abundant light brown gelatinous matrix (plectenchyma); outer ectal exciple with pustules composed of closely septate, prismatic to angular cells, dark brownish, cells more densely packed than in the inner ectal exciple, cells covered by a dark brown pigmented exudate. Asexual morph in culture with short-cylindric, curved, 0-septate, hyaline conidia formed at a single, apical conidiogenous locus on flask-shaped, phialidic conidiogenous cells. Conidiogenous cells solitary or with several cells held on a single, short, cylindric basal cell, on hyphae grouped into ropey, synemmatous structures.

\section{Aotearoamyces nothofagi P.R. Johnst., J.A. Cooper \& Quijada, sp. nov. Mycobank MB825176}

Etymology: The specific epithet refers to the generic name of the host plant in the holotype (Nothofagus).

Diagnosis: Apothecia black, to $1 \mathrm{~mm}$ diam and height, erumpent, short to medium long stipitate, pulvinate-discoid to turbinate, arising from a common gelatinous stromatic

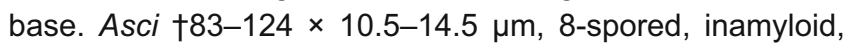
arising from croziers. Ascospores †17.5-31 × 3-5 $\mu \mathrm{m}$, cylindric-fusoid-clavate, $7-16$ phragmoseptate rarely with a longiseptum. Paraphyses apically up to $\nmid 1.5-2(2.5) \mu \mathrm{m}$ wide, flexuous to helicoid or curving downwards (hooked) and embedded in an olive-brownish gelatinous matrix. Conidia observed in culture, produced from phialides. Conidiogenous cells held on well-developed conidiophores arranged in small synnematous structures, forming consistently curved vermiform conidia. Conidiomata not observed in cultures.

Type: New Zealand: South Island: Craigiebrun, on Nothofagus solandri, 7 May 2010, N. Siegel (PDD 95741 holotype).

Description: Apothecia pulvinate-discoid to turbinate, 0.4-1 $\mathrm{mm}$ diam, strongly gelatinous, erumpent from bark, disc plane to slightly convex when fresh, round or somewhat irregular when crowded; margin thin, distinct, slightly lacerate, short to medium long stipitate $(0.2-0.7 \mathrm{~mm}$ diam), stipe tapering downward, apically almost as broad as disc; in groups, rarely solitary, arising from a common gelatinous stromatic base; black (267.Black) to deep greyish blue (187.d.gy.B), shiny when moist, shrinking on drying to \pm half the size; exterior strongly roughened. Asci †(83-)101.5-109.5(-124) × (10.5-) 12-13(-14.5) $\mu \mathrm{m}$, cylindric-clavate, 8-spored, inamyloid, apex hemispherical, spores 2-3-seriate, arising from croziers; ascus wall at apex and partly also laterally slightly thickened in dead state to $+0.5-1.5(-2) \mu \mathrm{m}$. Ascospores †(17.5-)23.5-25.5(-31) $\times(3-) 3.5-4(-5) \mu \mathrm{m}$, cylindric-fusoid to fusoid-clavate, ends obtuse to subacute, hyaline, straight or slightly curved, with (7-)13-14(-16) transversal septa (rarely 1 longiseptum), each cell with one refractive lipid guttule ( $\mathrm{LBs}$, tested in $\mathrm{KOH}$ ), never seen to form conidia on the spores. Paraphyses filiform, apex cylindrical to slightly clavate, flexuous to helicoid or curving downwards (hooked), agglutinated and intertwined among each other, embedded in an olive-brownish gelatinous matrix, terminal cell $\dagger(7-) 11-17(-27.5) \times 1.5-2(-2.5) \mu \mathrm{m}$, cell below $\dagger(10-)$ 13-16.5(-19.5) $\times(1-) 1.5-2 \mu \mathrm{m}$, frequently branched at apex, cells \pm equidistantly septate but terminal cell slightly shorter than lower cells. Ectal exciple †150-600 $\mu \mathrm{m}$ thick, inner layers of textura intricata composed of a loose net of

Fig. 3. Morphological features of Aotearoamyces nothofagi (PDD 95741, 80575). A. Apothecia in fresh state. B. Exciple: B1-2. section at flank, B3. Ectal exciple cells at flank. C. Asci. D. Paraphyses. E. Ascospores. Dead state, mounted in: $\mathrm{CR}=\mathrm{C} 3, \mathrm{D} 1, \mathrm{E} 1 ; \mathrm{KOH}=\mathrm{B} 1-3, \mathrm{C} 1-2, \mathrm{C6}, \mathrm{D} 2, \mathrm{E} 2, \mathrm{E} 4$; $M L Z=C 4-5$, E3. Bars: A1 = $500 \mu \mathrm{m} ; \mathrm{A} 2-3=2 \mathrm{~mm} ; \mathrm{B} 1-2, \mathrm{C} 1, \mathrm{C} 5=50 \mu \mathrm{m} ; \mathrm{B} 3, \mathrm{C} 2-4, \mathrm{C} 6, \mathrm{D} 1-2, \mathrm{E} 1-4=10 \mu \mathrm{m}$. 


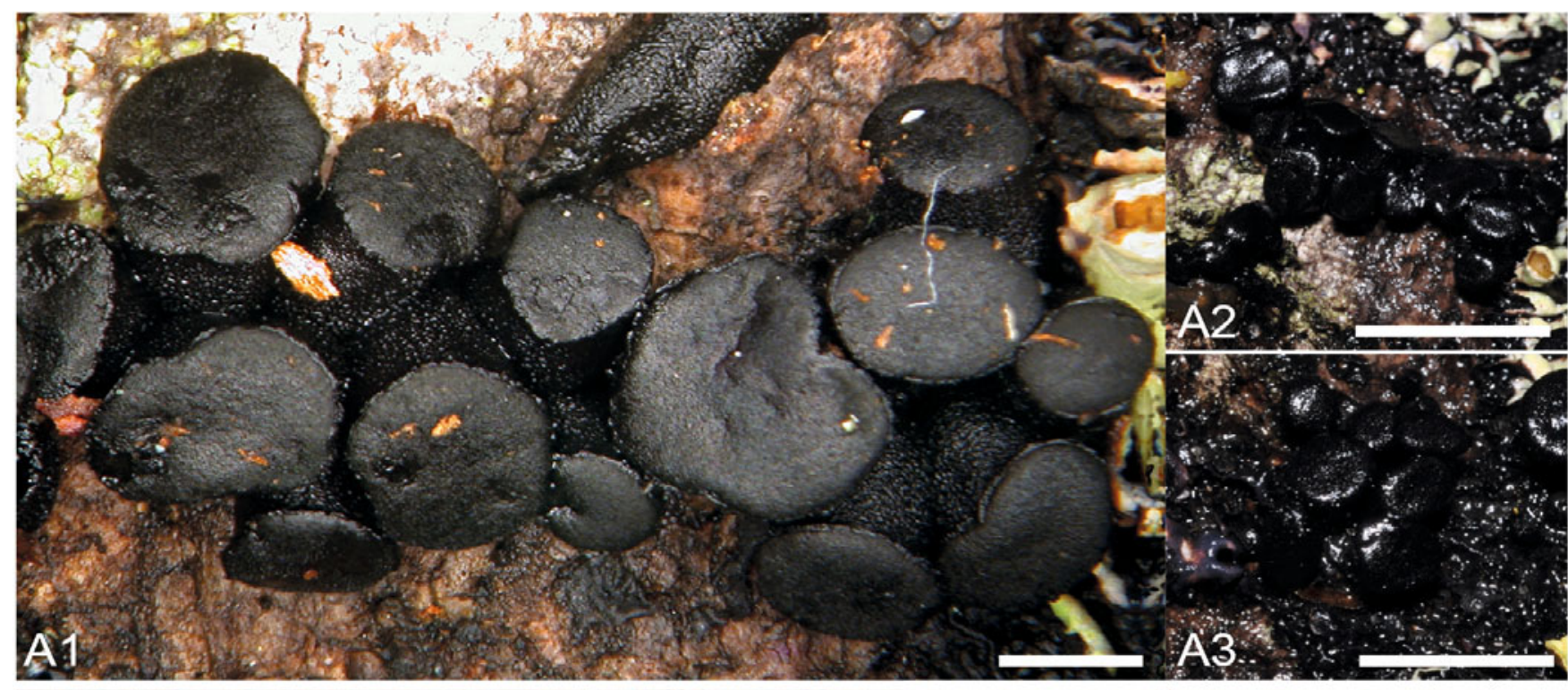

D
$\frac{1}{n}$
든

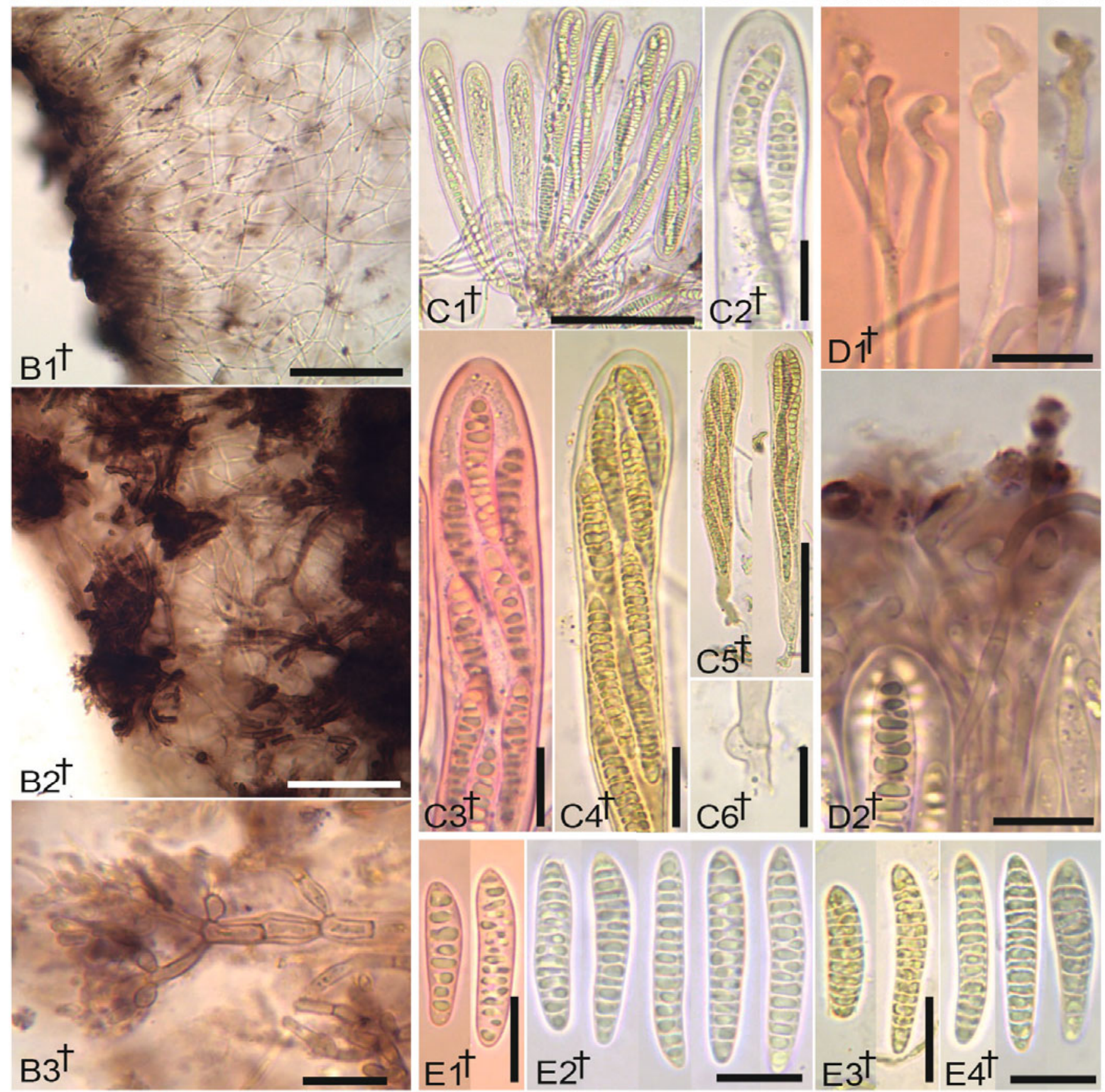



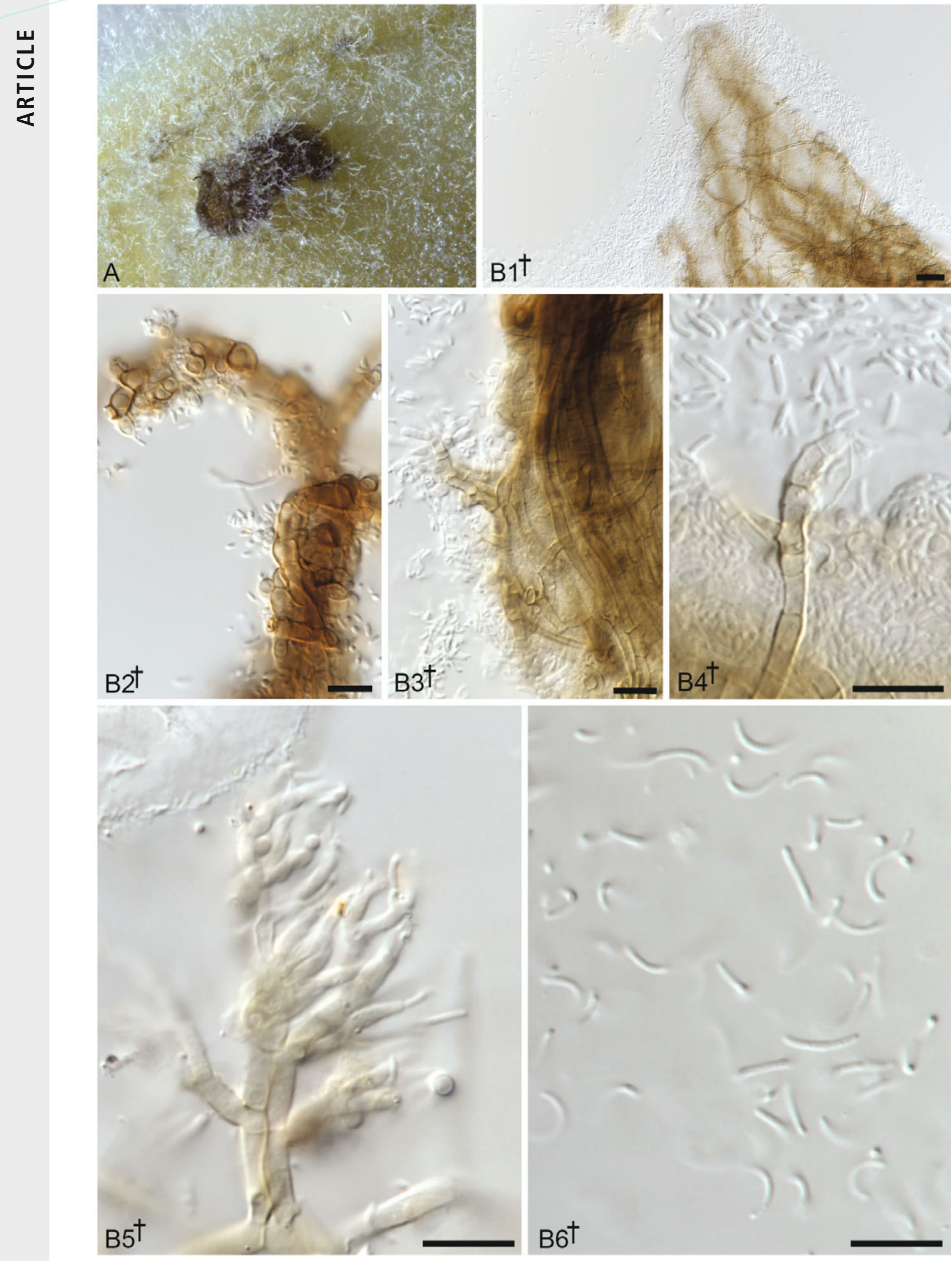
narrow, hyaline hyphae, distantly septate, strongly spaced, \pm vertically oriented and embedded in an abundant, light brown gelatinous matrix; outermost layer $+(5.5-) 7-13(-17.5) \mu \mathrm{m}$ thick at margin, $\dagger(16.5-) 24.5-37.5(-64) \mu \mathrm{m}$ thick at flanks, with pustules of closely septate, prismatic to angular cells, dark brownish, thick-walled and frequently branched, covered with a dark brown pigmented exudate, individual cells $\dagger 6-10$ $\times 2.5-3 \mu \mathrm{m}$ at margin, †(4-)6-7.5(-9) x (1.5-)2.5-3(-4) $\mu \mathrm{m}$ at lower flank and base, cell walls $\uparrow 0.5-1 \mu \mathrm{m}$ thick. Medullary exciple indistinctly differentiated from the ectal exciple and progressively changing toward the hymenium the hyphae becoming more closely spaced, hyphae $\dagger(0.5) 1-1.5 \mu \mathrm{m}$ wide. Tissues releasing a yellowish pigment in $\mathrm{KOH}$. Culture from germinated ascospores about $40 \mathrm{~mm}$ diam after $4 \mathrm{wk}$, aerial mycelium sparse, grouped in ropey strands on which the conidia are formed, colonies dark olivaceous to dark reddish brown. Asexual morph in culture with curved, 0-septate, hyaline conidia $\dagger(3-) 4-7.5(-8.5) \times(0.5-) 1(-1.5) \mu \mathrm{m}$, formed on flask-shaped conidiogenous cells $\dagger(4-) 5.5-7(-9) \times(1.5-)$ $2(-3.5) \mu \mathrm{m}$, conidiogenous cells sometimes in groups of $3-4$ held on a simple basal conidiophore of $+(4.5-) 6(-8.5) \times(1.5-)$ $2.5(-3) \mu \mathrm{m}$, conidiogenesis phialidic without collarette.

Other specimens examined: New Zealand: South Island: Abel Tasman National Park, on unidentified wood, 14 May 2004, P.R. Johnston D1844 (PDD 80575, ICMP 21037); Arthur's Pass National Park, on unidentified wood, 5 May 1989, P.R. Johnston D368, G.L. Barron, P.K. Buchanan \& M. Rajchenberg (PDD 55517, ICMP 21038); Otago Lakes, Routeburn Track carpark, on unidentified fallen wood in Nothofagaceae forest, 7 May 2016, S. McMullan-Fisher (PDD 110269).

\section{DISCUSSION}

Throughout its history, the number of species, genera and families in the order Phacidiales has changed considerably (Fig. 1). The order as circumscribed by Bessey (1907), who included six genera and three families, was differently conceived by Höhnel (1917), who expanded the order to include 52 genera in six families. In the 1970s (e.g. Korf 1973, Dennis 1978) the rhytismataceous fungi were often included in Phacidiales, although today they are placed in the separate order Rhytismatales. The most current classification of Phacidiales includes about 29 genera, most of them distributed across three families and one informal taxonomic lineage (Crous et al. 2014, Baral 2016, Suija et al. 2017). These changing concepts reflect the changes in emphasis placed on macro- and micromorphological features, as well as the impact of molecular phylogenetics. Molecular studies have allowed genera known only from an asexual morph, such as Collophorina, to be placed in Phacidiales (Baral loc. cit.). Our phylogenetic analyses allowed placement of Epithamnolia, a conidial fungus previously reported as incertae sedis in Phacidiales (Suija et al. 2017), in the Mniaecia clade for the first time.
Five species, known only from asexual morphs that were isolated from woody necroses in peach and nectarine, were included when Damm et al. (2010) erected the genus Collophora with C. africana, C. capensis, C. paarla, C. pallida, and $C$. rubra, the type species). Since that name was illegitimate as a later homonym of Collophora Mart. 1830, Apocynaceae, the species were recombined into the new genus Collophorina, and the number of species reduced from seven to five due to synonymy of $C$. capensis with $C$. africana, and C. pallida with C. paarla (Wijayawardene et al. 2017). Damm et al. (2010) placed the genus in Leotiomycetes as incertae sedis. In the same work, the authors remarked "although these species form two clades in the LSU phylogeny, they are placed in one genus, because of their similar morphological features and the lack of morphological characters distinguishing the two clades". In our analyses, the genus is also paraphyletic in agreement with Damm et al. (2010) (Fig. 2): Collophorina paarla belongs in one supported clade (Fig. 2, Clade J), and C. africana and the type species C. rubra in a different strongly supported clade.

In the discussion about C. pallida, Damm et al. (2010) said that " $C$. paarla and $C$. pallida are the only Collophora species for which endoconidia have been observed". This morphological feature could be used to support the splitting of Collophorina into at least two genera. Aotearoamyces is most closely related to the clade containing the Collophorina species with endoconidia, but we did not see any endoconidia form in our culture studies. Compared to Damm et al.'s illustrations and descriptions, the conidiogenus cells of Aotearomyces nothofagi are held on well-developed synnematous conidiophores bearing conidia that are consistently curved.

The sexual morph of Aotearoamyces shares several morphological traits with Tympanidaceae (Fig. 5): (1) the asci are inamyloid, apically and/or laterally thick-walled and arising from croziers (Fig. 5, A4-H4); (2) the ascospores are phragmosporous, cylindric-fusoid to fusiform-clavate (Fig. $5, \mathrm{~A} 3-\mathrm{H} 3$ ); and (3) the paraphyses are usually agglutinated and embedded in a dark amorphous exudate (Fig. 5, A5-H5). However, Aotearoamyces also differs in many aspects: conidia are not present inside the asci or attached to ascospores (Fig. 5, $\mathrm{C}_{2}$ and $\mathrm{E}_{2}$ ), which allows it to be distinguished from Holwaya, Tympanis and most Claussenomyces species (Fig. 5, B3). Claussenomyces jahnianus, lacking reports of conidia formed on ascospores, can be differentiated from Aotearomyces by the acicular ascospores and apically moniliform, closely septate paraphyses (Quijada 2015). The exciple of Aotearoamyces, of textura intricata with widely spaced hyphae immersed in gel (Fig. 5, A2), differs completely from the exciple in Grovesiella (Fig. 5, F2: textura angularis to $t$. prismatica) and Pragmopora (Fig. 5, G2: t. oblita); these genera also differ in the paraphyses never being helicoid or hooked at the apex as those in Aotearoamyces (Fig. 5, A5). The genera Myriodiscus (Fig. 5, H2), Durandiella (Fig. 5, D2), and Aotearoamyces have a similar plectenchymatous exciple. Durandiella differs in the morphology of the paraphysis apex

Fig. 4. Cultural features of Aotearoamyces nothofagi (PDD 95741, 55517; ICMP 21037, 21038). A. A part of an apothecium in culture. B1-4. Vegetative hyphae. B5. Conidiogenous cells. B6. Conidia. All in dead state (mounted in KOH). Bars: B1 = $20 \mu \mathrm{m}$; B2-6 = $10 \mu \mathrm{m}$. 


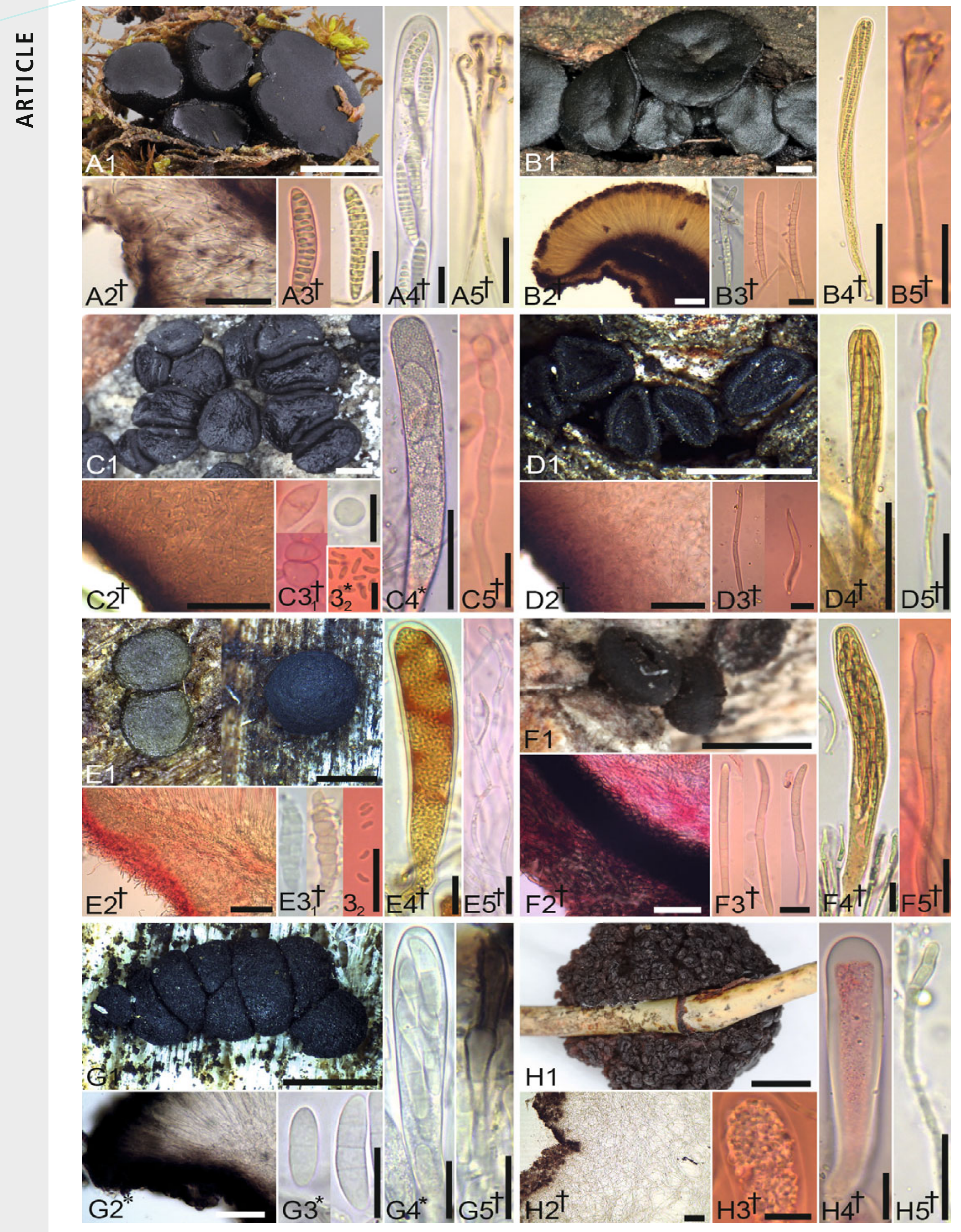


(Fig. 5, D5: straight vs. 1e: curved to helicoid) and ascospores (Fig. 5, D3: acicular-fusiform to falcate vs. A3: cylindrical-fusoid to fusoid-clavate); and Myriodiscus differs in having polysporus asci (Fig. 5, H3) and in macroscopic appearance (Fig. 5, H1: discoid apothecia aggregated in a subglobose fructification vs. A1: turbinate apothecia sharing a stromatic base). Given the above, we concluded that Aotearoamyces is a new monotypic genus in Phacidiales, phylogenetically related to "Collophorina" paarla and morphologically sharing several features with other genera of Tympanidaceae that have a sexual morph.

\section{ACKNOWLEDGEMENTS}

L.Q. thanks the "Fundación Ramón Areces" for support. This study is part of the project "DNA barcoding for plant-pathogens diagnostic and monitoring: Forest diseases and turbo-taxonomy in Tympanidaceae as a case of study", and also the fellowship programme Becas Fundación Ramón Areces para Estudios Postdoctorales, XXIX Convocatoria para Ampliación de Estudios en el Extranjero en Ciencia de la Vida y de la Materia. P.R.J. and J.A.C. were supported with funding from the Science and Innovation Group of the New Zealand Ministry of Business, Innovation and Employment through the Manaaki Whenua Landcare Research Systematics Portfolio. Also, we would like to thank Hans-Otto Baral for revising the manuscript.

\section{REFERENCES}

Ainsworth GC, Bisby G.R. (1943) A Dictionary of the Fungi. Kew: Imperial Mycological Institute.

Ainsworth GC, Bisby GR (1950) A Dictionary of the Fungi. $3^{\text {rd }}$ edn. Kew: Commonwealth Mycological Institute.

Ainsworth GC (1961) Ainsworth \& Bisby's Dictionary of the Fungi. $5^{\text {th }}$ edn. Kew: Commonwealth Mycological Institute.

Ainsworth GC, James PW, Hawksworth DL (1971) Ainsworth \& Bisby's Dictionary of the Fungi. $6^{\text {th }}$ edn. Kew: Commonwealth Mycological Institute.

Akaike $H$ (1974) A new look at the statistical model identification. IEEE Transactions on Automatic Control 19: 716-723.

Anonymous (1976) ISCC-NBS Color-name Charts illustrated with centroid colors. Washington DC: Inter-Society Color Council, National Bureau of Standards.

Baral HO (1992) Vital versus herbarium taxonomy: morphological differences between living and dead cells of ascomycetes, and their taxonomic implications. Mycotaxon 44: 333-390.

Baral HO (2016) Inoperculate discomycetes. In: Syllabus of Plant families. A. Engler's Syllabus der Pflanzenfamilien. Vol. 1(2), Ascomycota (Jaklitsch W, Baral HO, Lücking R, Lumbsch T, eds): 55-221. $13^{\text {th }}$ edn. Stuttgart: Borntraeger Science Publishers.
Bessey CE (1907) A synopsis of plant phyla. University of Nebraska Studies 7: 275-373.

Bunyard BA, Nicholson MS, Royse DJ (1994) A systematic assessment of Morchella using RFLP analysis of the $28 \mathrm{~S}$ ribosomal RNA gene. Mycologia 86: 762-772.

Castresana J (2000) Selection of conserved blocks from multiple alignments for their use in phylogenetic analysis. Molecular and Evolution 17: 540-552.

Crous PW, Quaedvlieg W, Hansen K, Hawksworth DL, Groenewald JZ (2014) Phacidium and Ceuthospora (Phacidiaceae) are congeneric: taxonomic and nomenclatural implications. IMA Fungus 5: 173-193.

Damm U, Fourie PH, Crous PW (2010) Coniochaeta (Lecythophora), Collophora gen. nov. and Phaeomoniella species associated with wood necroses of Prunus trees. Persoonia 24: 60-80.

Dennis RWG (1978) British Ascomycetes. $2^{\text {nd }}$ edn. Vaduz: J. Cramer..

DiCosmo F, Nag Raj TR, Kendrick WB (1984) A revision of the Phacidiaceae and related anamorphs. Mycotaxon 21: 1-234.

Eriksson OE (2005) Outline of Ascomycota - 2005. Myconet 11: $1-113$.

Eriksson OE (2006) Outline of Ascomycota - 2006. Myconet 12: $1-82$.

Hawksworth DL, Kirk PM, Sutton BC, Pegler DN (1995) Ainsworth \& Bisby's Dictionary of the Fungi. $8^{\text {th }}$ edn. Wallingford: CAB International.

Hawksworth DL, Sutton BC, Ainsworth GC (1983) Ainsworth \& Bisby's Dictionary of the fungi (including the lichens). $7^{\text {th }}$ edn. Kew: Commonwealth Mycological Institute.

Höhnel F (1917) System der Phacidiales v. H. Berichte der Deutschen Botanischen Gesellschaft 34: 416-422.

Gardes M, Bruns TD (1993) ITS primers with enhanced specificity for basidiomycetes - application to the identification of mycorrhizae and rusts. Molecular Ecology 2: 113-118.

Johnston PR, Park D (2013) The phylogenetic position of Lanzia berggrenii and its sister species. Mycosystema 32: 366-385.

Katoh K, Misawa K, Kuma K, Miyata T (2002) MAFFT, a novel method for rapid multiple sequence alignment base don fast Fourier transform. Nucleic Acid Research 30: 3059-3066.

Katoh K, Toh H (2008) Improved accuracy of multiple ncRNA alignment by incorporating structural information into a MAFFTbased framework. BMC Bioinformatics 9: 212.

Kirk PM, Cannon PF, David JC, Stalpers JA (2001) Ainsworth \& Bisby's Dictionary of the Fungi. $9^{\text {th }}$ edn. Wallingford: CAB International.

Kirk PM, Cannon PF, Minter DW, Stalper JA (2008) Ainsworth \& Bisby's Dictionary of the Fungi. $10^{\text {th }}$ edn. Wallingford: $C A B$ International.

Korf RP (1973) Discomycetes and Tuberales. In: The Fungi: an advanced treatise. Vol. IVA. A Taxonomic Review with keys: Ascomycetes and Fungi Imperfecti (Ainsworth GC, Sparrow FK, Sussman AS, eds): 249-319. New York: Academic Press.

Fig. 5. Morphological features of Aotearoamyces nothofagi compared to those of other genera in Tympanidaceae: A. Aotearomyces nothofagi (PDD 95741, 80575). B. Holwaya mucida (Dragisa Savic herb. without number; CUP 60122, 2006) C. Tympanis spp. (NYBG 423829, 1168034, 1168036; TAAM 165632) D. Durandiella gallica (S F196603, Baral herb. HB 9244). E. Claussenomyces spp. (TFCMic. 23325, 23950, 24408, 24011; CUP 3938). F. Grovesiella abieticola (DAVFP 23014; NYBG 1293222). G. Pragmopora amphibola (TFCMic. 23861, 23922, 23726). H. Myriodiscus sparassoides (TFCMic. 24582). Morphological features compared: 1. Apothecia, 2. section of the exciple, 3. ascospores (with or without conidia or ascoconidia), 4. asci, and 5. paraphyses. Mounted in: water = C4, D2, G2-G4, KOH = A2, A4, C2, E3, G5, H2, H5; CR = A3, B3, B5, C3 ${ }_{1-2}, \mathrm{C} 5$,

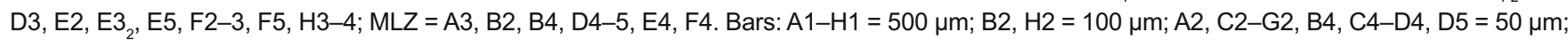
A3-B3, C3 ${ }_{1}$ D3, E3, F3-H3, A4, E4-H4, A5-C5, E5-H5; $5=10 \mu \mathrm{m}$. 
Korf RP, Lizoň P (2000) Validation of Nannfeldt's ordinal name Helotiales. Mycotaxon 75: 501-502.

LoBuglio KF, Pfister DH (2010) Placement of Medeolaria farlowii in the Leotiomycetes, and comments on sampling within the class. Mycological Progress 9: 36-368.

Lumbsch HT, Huhndorf SM (2007) Outline of Ascomycota - 2007. Myconet 13:1-58.

Lumbsch HT, Huhndorf SM (2010) Outline of Ascomycota - 2009. Myconet 14:1-40.

Posada D (2008) jModelTest: phylogenetic model averaging. Molecular Biology and Evolution 25: 1253-1256.

Quijada L, Baral HO, Jaen-Molina R, Weiss M, Caujapé-Castells J, Beltrán-Tejera E (2014) Phylogenetic and morphological circumscription of the Orbilia aurantiorubra group. Phytotaxa 175: 1-18.

Quijada L (2015) Estudio de los órdenes Helotiales s.l. y Orbiliales (Ascomycota, Fungi) en la Isla de Tenerife. PhD thesis, Universidad de La Laguna.

Suija A, van den Boom P, Zimmermann E, Zhurbenko MP, Diederich $\mathrm{P}$ (2017) Lichenicolous species of Hainesia belong to Phacidiales (Leotiomycetes) and are included in an extended concept of Epithamnolia. Mycologia 109: 882-899.
Talavera G, Castresana J (2007) Improvement of phylogenies after removing divergent and ambiguously aligned blocks from protein sequence alignments. Systematic Biology 56: 564-577.

Van Vooren N (2005) Mniaecia gloeocapsae (Boud.) van Vooren. Bulletin Mensuel de la Société Linnéenne de Lyon 74: 19.

Vilgalys R, Hester M (1990) Rapid genetic identification and mapping of enzymatically amplified ribosomal DNA from several Cryptococcus species. Journal of Bacteriology 172: 4238-4246.

White TJ, Bruns T, Lee S, Taylor J (1990) Amplification and direct sequencing of fungal ribosomal RNA genes for phylogenetics. In: PCR Protocols: a guide to methods and applications (Innis MA, Gelfand DH, Sninsky JJ \& White TJ, eds): 315-322. San Diego: Academic Press.

Wijayawardene NN, Hyde KD, Rajeshkumar KC, Hawksworth DL, Madrid H, et al. (2017) Notes for genera Ascomycota. Fungal Diversity 86: 1-594. 